\title{
Effects of African Nutmeg (Monodora myristica) spice in aflatoxin-infected diets on growth Performance of Japanese Quails (Cortunix Cortunix)
}

\author{
${ }^{1}$ Ukoha, O. A. and ${ }^{1}$ Onunkwo, D. N.
}

${ }^{1}$ Department of Animal Nutrition and Forage Science, College of Animal Science

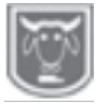

Abstract and Animal Production, Michael Okpara University of Agriculture, Umudike, Umuahia, Abia State, Nigeria.

*Corresponding author's email: donunkwo1@gmail.com Phone No.: 08033388622

A research work was carried out to evaluate the effects of toasted Monodora myristica spice as feed additive in quail diet in a completely randomized design. The proximate, vitamin and mineral composition and anti-nutritional factors, growth performance, cut parts and organ characteristics, biochemical parameters and egg quality traits were evaluated in this study that lasted for fifteen weeks. A total of 120 day-old quail chicks were brooded for 14 days. Thereafter, they were allocated to four dietary treatments designated D1, D2, D3 and D4 also having 0, 0.5, 1.0 and 1.5\% Monodora myristica respectively. Each treatment was replicated three times at 10 quails (2 males: 8 females) per replicate. Growth performance and carcass characteristics study lasted for 7 weeks while eggs were collected for four weeks. Daily feed intake was reported to be $2.39 \mathrm{~g} / \mathrm{bird} /$ day, $2.83 \mathrm{~g} / \mathrm{bird} /$ day, $3.22 \mathrm{~g} / \mathrm{bird} /$ day and $3.15 \mathrm{~g} / \mathrm{bird} /$ day respectively for 0, 0.5, 1.0 and 1.5\% Monodora myristica-flavoured diets. There was no significant $(P>0.05)$ increase in the daily feed intake though it increased only numerically as level of inclusion increased from $0 \%$ to $1.0 \%$ but decreased at the level above $1.0 \%$. There were significant $(P<0.05)$ differences in the average daily weight gain and feed conversion ratio among the varying treatments. Average daily weight gains for the groups were $1.68 \mathrm{~g} / \mathrm{b} / \mathrm{d}, 2.18 \mathrm{~g} / \mathrm{b} / \mathrm{d}, 3.35 \mathrm{~g} / \mathrm{b} / \mathrm{d}$ and $3.37 \mathrm{~g} / \mathrm{b} / \mathrm{d}$ respectively for $\mathrm{D} 1, \mathrm{D} 2, \mathrm{D} 3$ and $\mathrm{D} 4$. Significant $(P<0.05)$ differences were observed in the cut parts and organ characteristics. From the results, Monodora myristica was not observed to be detrimental to the quails with respect to the weight of organs and cut parts. Dressed weight increased as level of inclusion increased up to $1.0 \%$ but then declined afterwards to $137.69 \mathrm{~g}$. Liver weights were $3.55 \%$, $2.55 \%, 1.79 \%$ and $1.77 \%$ respectively for D1, D2, D3 and D4. Quails fed the control diet recorded the highest liver weight $(P<0.05)$ of $3.55 \%$ indicating stress condition. The low liver weight in quails fed Monodora-flavoured diet indicates potential of Monodora to protect the liver from free radicals that cause stress. Breast meat was significantly reduced at $1.0 \%$ and $1.5 \%$ M. myristica inclusion

\section{Keywords: Monodora myristica, Growth performance, Japanese quail}

\section{Introduction}

Poultry is one of the major sources of animal protein and generally accepted worldwide (F.A.O. 1990). Chicken, duck, guinea fowl, turkey are the major classes of poultry. The Japanese quail was introduced in Nigeria in 1992. In the recent times, attempts are being made to domesticate and popularize quail production. Since 1993, quail farming has been growing in popularity in Nigeria (Daikwo, et al., 2011). Quails are small bodied birds of weight varying between 150 - $700 \mathrm{~g}$ when fully matured. It has feathers and the female lay small eggs of less than $15 \mathrm{~g}$ compared to egg laying chicken of about $40-70 \mathrm{~g}$. The meat is a delicacy and highly nutritious. The high prolificacy and hardy nature of the quail 
bird as well as the recent discovery of the health benefits of its egg have made rearing of Japanese quails suitable for the resource poor tropical Sub-Saharan African countries.

Egg remains the only source of supply of day-old chicks for the success of the poultry production chain. External and internal quality of egg is of major importance to both layer and breeder industries worldwide. Production of eggs and its quality are influenced by many factors both genetic and non-genetic such as breed, nutrition, mortality rate, culling age and season (Oluyemi and Robert 2000.). Hen's egg has been traditionally considered as an important source of nutrients for humans (Fetuga, et al., 1976). It is a source of protein, lipids, mineral and vitamin easily renewable. The study involved assessment of the effect of Monodora myristica on the growth performance (feed intake, weight gain and feed conversion ratio) of the quail birds and evaluation of the effect of Monodora myristica on their carcass characteristics.

\section{Materials and methods \\ Experimental Location}

The Research work was carried out at the Poultry Unit of the Teaching and Research farm of Michael Okpara University of Agriculture, Umudike located within the tropical rain forest zone and lies between latitude $5^{\circ} 29^{\prime} \mathrm{N}$ and longitude $7^{\circ} 32^{\prime} \mathrm{E}$ and $122 \mathrm{~m}$ above sea level and the environment is characterized by an annual rainfall ranging from $60-68 \mathrm{~mm}$. The ambient temperature ranges between $30^{\circ} \mathrm{C}-32^{\circ} \mathrm{C}$ while the relative humidity is in the range of $60-80 \%$ (Eke-Okoro, 1999.)

\section{Test material}

Seeds of Monodora myristica were bought from Ndoro market in Ikwuano Local
Government Area of Abia State. They were cleaned and toasted for one hour at $65^{\circ} \mathrm{Cmilled}$ into powder and bottled in air tight container for the chemical analysis and for the feeding trial.

\section{Proximate composition analysis}

Determination of the proximate composition of the test ingredient was carried out according to the procedure of AOAC (1990).

\section{Experimental birds and design}

One hundred and twenty unsexed quail birds were brooded for 2 weeks in deep litter and thereafter allocated to the four experimental diets designated as D1, D2, D3 and D4 in a Completely Randomized Design with 30 birds per treatment and replicated three times with 10 quails per replicate. The dietary treatments designated D1, D2, D3 and D4 contained 0.0, 1.0, 1.5 and $2.0 \%$ Monodora myristica respectively (Table1). Throughout the experimental period, the quails were given feed and water ad-libitum and all the routine vaccination programs were duly administered. Feed consumption was measured daily while the weight of the birds were taken weekly in groups.

At the end of the rearing phase that lasted for 7 weeks, the quails were evaluated for growth performance parameters.

Two quails per replicate were randomly selected at the end of the metabolic trial. The birds were then starved for twenty-four hours two birds were selected, weighed and slaughtered by severing the jugular vein. The birds were bled, dipped in hot water for 10 minutes and then de-feathered. The head, neck and visceral were separated. Thighs, drumstick, breast meat, back cut, heart, kidney, emptied gizzard were weighed.

\section{Statistical analysis}

The data collected were subjected to 


\section{Ukoha and Onunkwo}

Analysis of Variance (ANOVA) for Completely Randomized Design. Where significant differences occurred, means were further subjected to Duncan's Multiple Range Test (Duncan, 1952) as packaged in SPSS (SPSS 2006) for windows; version 16, SPSS Inc.

Table 1: Dietary composition of the experimental diets supplemented with Monodora myristica

\begin{tabular}{lllll}
\hline Ingredients & D1 (0\%) & D2 (1.0\%) & D3 (1.5\%) & D4 (2.0\%) \\
\hline Maize & 25.00 & 25.00 & 25.00 & 25.00 \\
Maize offal & 15.00 & 15.00 & 15.00 & 15.00 \\
Wheat offal & 15.00 & 15.00 & 15.00 & 15.00 \\
P.K.C & 4.00 & 4.00 & 4.00 & 4.00 \\
G.N.C & 4.00 & 4.00 & 4.00 & 4.00 \\
S.B.M & 15.00 & 15.00 & 15.00 & 15.00 \\
Fish meal & 5.00 & 5.00 & 5.00 & 5.00 \\
M. myristica & 0.00 & 0.50 & 1.00 & 1.50 \\
Methionine & 0.50 & 0.50 & 0.50 & 0.50 \\
Lysine & 0.50 & 0.50 & 0.50 & 0.50 \\
Bone meal & 4.00 & 4.00 & 4.00 & 4.00 \\
Oyster & 2.00 & 2.00 & 2.00 & 2.00 \\
vit/min premix & 0.25 & 0.25 & 0.25 & 0.25 \\
Salt & 0.25 & 0.25 & 0.25 & 0.25 \\
Rice Bran & 9.50 & 9.50 & 9.50 & 9.50 \\
Total & 100 & 100 & 100 & 100 \\
Calculated Analysis & & & & \\
ME(Kcal/kg) & 2739.89 & 2709.36 & 2694.10 & 2678 \\
CP (\%) & 20.61 & 20.31 & 20.36 & 20.15 \\
EE (\%) & 6.30 & 6.22 & 6.35 & 6.26 \\
Lys (\%) & 1.10 & 1.15 & 1.15 & 1.13 \\
Meth (\%) & 0.40 & 0.45 & 0.45 & 0.45 \\
Ca (\%) & 2.20 & 2.21 & 2.26 & 2.26 \\
P (\%) & 0.75 & 0.80 & 0.80 & 0.80 \\
\hline P.K\% G.N.C & B. B. & & & \\
\hline
\end{tabular}

P.K.C; G.N.C and S.B.M represent palm kernel cake, groundnut cake and soybean meal respectively. $\mathrm{CP}, \mathrm{EE}$, Lys, Meth, Ca and P represent crude protein, ether extract, lysine, methionine, calcium and phosphorus respectively

\section{Results and Discussion}

Growth performance of quails fed toasted Monodora-flavoured diets

The effects of Monodora myristica on the growth performance of Cortunix cortunix are summarized in Table 2.

The average daily feed intake recorded were $2.39 \mathrm{~g} / \mathrm{b} / \mathrm{d}, 2.83 \mathrm{~g} / \mathrm{b} / \mathrm{d}, 3.02 \mathrm{~g} / \mathrm{b} / \mathrm{d}$ and $3.15 \mathrm{~g} / \mathrm{b} / \mathrm{d}$ while final body weights were $76.89 \mathrm{~g} / \mathrm{b}, 97.89 \mathrm{~g} / \mathrm{b}, 147.03 \mathrm{~g} / \mathrm{b}$ and $147.96 \mathrm{~g} / \mathrm{b}$ for quails fed diets $1,2,3$ and 4 respectively. The Gain in body weight of the quails was observed to be $1.68 \mathrm{~g} / \mathrm{b} / \mathrm{d}$,
$2.18 \mathrm{~g} / \mathrm{b} / \mathrm{d}, 3.35 \mathrm{~g} / \mathrm{b} / \mathrm{d}$ and $3.37 \mathrm{~g} / \mathrm{b} / \mathrm{d}$ for $\mathrm{D}_{1}$, $\mathrm{D}_{2}, \mathrm{D}_{3}$ and $\mathrm{D}_{4}$ respectively. The result also revealed a feed conversion ratio of 1.42 , $1.30,0.90$ and 0.93 respectively for quails fed $D_{1}, D_{2}, D_{3}$ and $D_{4}$ respectively.

Monodora myristica had no significant ( $\mathrm{P}>0.05$ ) effect on the feed consumption of quails. The quails fed $1.5 \%$ and $2.0 \%$ Monodora myristica significantly $(\mathrm{P}<0.05)$ recorded higher final weight than those fed the control diets and $1 \%$ Monodora myristica flavoured diets. The Monodora at $1.5 \%$ and $2.0 \%$ improved $(\mathrm{P}<0.05)$ the 
mean daily body weight gain over the control diet. There were significant differences $(\mathrm{P}<0.05)$ in the feed conversion ratios of the quails fed the various diets. The best feed conversion ratio was observed in diets 4 even though it was statistically similar $(\mathrm{P}>0.05)$ to that obtained in diet 3 . The conversion rate was poorest for the quails fed control diet.

Monodora myristica appeared to exhibit appetite stimulating properties like others spices such as turmeric (Wenk, 2002.), ginger (Okoye, et al., 2006). A similar report was given by Ukoha, (2011) when Monodora myristica was included in broiler diet. Beyond 1.0\%, Monodora did not make any significant improvement in feed intake. The result may be an indication is an indication that quails like chickens, have well developed taste birds, in line with the observation and report by Holdas and May (1966). The quails may have been able to detect the flavor added by Monodora spice (Samarasinghe, and Wenk, (2002).

Monodora spice was observed to improve the weight gain of the quails $(\mathrm{P}<0.05)$ over the control fed quails. The highest average daily weight gain $(3.37 / \mathrm{b} / \mathrm{d})$ was observed among the quails fed diets having $1.5 \%$ Monodora. However, there was no significant difference in average weight gain between quails fed diet $3(1.0 \%$ Monodora) and diet 4 (1.5\% Monodora). The average daily weight gain was observed to increase significantly $(\mathrm{P}<0.05)$ as Monodora inclusion increased from $0.5 \%$ to $1.0 \%$ but was not statistically better beyond this level.

The increase in weight gain for quails fed Monodora-flavoured diets over the control is in line with the report by Ukachukwu (2000) and Adeniji and Balogun (2000) and Jamroz and Kamel (2000) who reported an increase in body weight gain of broilers fed garlic and ginger, mixed spices, vanilla and curry mixed spiced respectively.

Feed conversion ratio was significantly $(\mathrm{P}<0.05)$ improved over the control. The absence of Monodora myristica in quail diet resulted to the poor rate of conversion of feed to meat $1.42 \mathrm{~g}$ of feed was used to produce only weight increase by $1 \mathrm{~g}$. However, as Monodora was introduced into the diet at $0.5,1.0 \%$ and $1.5 \%$, the rate of conversion increased.

\section{The effects of toasted Monodora myristica spice on the carcass and organ characteristics of quails}

The weights of cut parts and organs proportions of quails fed Monodora myristica supplemented diets are presented in Table 3. Live weights recorded were $76.89 \mathrm{~g}, 97.89 \mathrm{~g}, 147.03 \mathrm{~g}$ and $147.96 \mathrm{~g}$ respectively for quails fed diets $\mathrm{D}_{1}, \mathrm{D}_{2}, \mathrm{D}_{3}$ and $\mathrm{D}_{4}$. Monodora myristica significantly $(\mathrm{P}<0.05)$ improved the live weight of the quails. The liveweights were observed to increase as the level of inclusion increased. Thigh weights were observed to be $1.69 \mathrm{~g}$ $(2.02 \%), 1.63,(1.67 \%), 1.82 \mathrm{~g}(1.24 \%)$ and $1.97 \mathrm{~g}(1.33 \%)$ for quails fed diets having varying levels of Monodora myristica. The breast-bone cut weight observed were $28.70 \mathrm{~g}(19.41 \%)$ for $0 \%$ Monodora diets while others measured 24.90g (16.94\%), $21.20 \mathrm{~g}(21.66 \%)$, and $20.40 \mathrm{~g}(26.55 \%)$ for quails fed $0.5 \%, 1.0 \%$ and $1.5 \%$ M.myristica.

The weights of the heart recorded were $2.04 \mathrm{~g}(2.65 \%), 2.12 \mathrm{~g} \quad(2.17 \%), 2.49 \mathrm{~g}$ $(1.69 \%)$ and $2.87(1.94 \%)$ for $\mathrm{D}_{1}, \mathrm{D}_{2}, \mathrm{D}_{3}$ and $\mathrm{D}_{4}$ respectively. Liver weights were observed to record $3.55 \%, 2.55 \%, 1.79 \%$ and $1.77 \%$ for the quails fed $0 \%, 1.0 \%$, $1.5 \%$ and $2 \%$ Monodora myristica respectively. The quails that were fed the Monodora-free diet had the largest liver size of $2.73 \mathrm{~g}(3.55 \%)$ while the quails fed Monodora flavoured diets at $0.5 \%, 1.0 \%$ and $1.5 \%$ recorded $2.50 \mathrm{~g}(2.55 \%) 2.63 \mathrm{~g}$ $(1.79 \%)$ and $2.62 \mathrm{~g}(1.77 \%)$ respectively. 
Ukoha and Onunkwo

Table 2: Effects of toasted Monodora myristica spice on the growth performance of quails

\begin{tabular}{lccccc}
\hline Parameters & (D1) 0\% & (D2)0.5\% & (D3)1.0\% & (D4)1.5\% & \multicolumn{1}{c}{ SEM } \\
\hline D.F.I $(\mathrm{g} / \mathrm{b} / \mathrm{d})$ & 2.39 & 2.83 & 3.22 & 3.15 & 1.21 \\
I.B.W $(\mathrm{g} / \mathrm{b})$ & 6.33 & 6.33 & 6.33 & 6.28 & 0.12 \\
F.B.W $(\mathrm{g} / \mathrm{b})$ & $76.89^{\mathrm{b}}$ & $97.89^{\mathrm{b}}$ & $147.03^{\mathrm{a}}$ & $147.96^{\mathrm{a}}$ & 14.21 \\
A.W.G $(\mathrm{g} / \mathrm{b} / \mathrm{d})$ & $1.68^{\mathrm{b}}$ & $2.18^{\mathrm{b}}$ & $3.35^{\mathrm{a}}$ & $3.37^{\mathrm{a}}$ & 0.63 \\
F.C.R & $1.42^{\mathrm{b}}$ & $1.30^{\mathrm{b}}$ & $0.96^{\mathrm{a}}$ & $0.93^{\mathrm{a}}$ & 0.24 \\
\hline
\end{tabular}

a,b,c $\_$means in a row with the same superscripts are not significantly $(p>0.05)$ different from one another. D.F.I, I.B.W, F.G.W, A.W.G and F.C.R represent daily feed intake, initial body weight, final body weight, average weight gain and feed conversion ratio respectively.

Table 3: Effect of toasted Monodora myristica on the cut parts/organ weight of quails

\begin{tabular}{llllll}
\hline Parameter & D1 (0\%) & D2 (0.5\%) & D3 (1.0\%) & D4 (1.5\%) & SEM \\
\hline Live weight (g) & $76.89^{\mathbf{b}}$ & $97.89^{\mathbf{b}}$ & $147.03^{\mathrm{a}}$ & $147.96^{\mathrm{a}}$ & 4.65 \\
D.F.W (\%) & 98 & 91 & 94 & 93 & 0.23 \\
D.W (g) & $75.35^{\mathrm{b}}$ & $89.08^{\mathrm{b}}$ & $138.21^{\mathrm{a}}$ & $137.60^{\mathrm{a}}$ & 4.21 \\
Thigh (\%) & $2.02^{\mathrm{a}}$ & $1.67^{\mathrm{a}}$ & 1.24 & 1.33 & 0.95 \\
Breast meat (\%) & $19.41^{\mathrm{d}}$ & $16.94^{\mathrm{c}}$ & $21.66^{\mathrm{b}}$ & $26.55^{\mathrm{a}}$ & 0.30 \\
Kidney (\%) & $5.07^{\mathrm{b}}$ & $3.30^{\mathrm{b}}$ & $2.24^{\mathrm{a}}$ & $2.48^{\mathrm{a}}$ & 0.38 \\
Liver (\%) & $3.55^{\mathrm{b}}$ & $2.55^{\mathrm{b}}$ & $1.79^{\mathrm{a}}$ & $1.77^{\mathrm{a}}$ & 0.25 \\
Provent (\%) & $0.87^{\mathrm{a}}$ & $0.79^{\mathrm{a}}$ & $0.61^{\mathrm{c}}$ & $0.74^{\mathrm{b}}$ & 0.05 \\
Herat (\%) & 2.65 & 2.17 & 1.69 & 1.94 & 0.13 \\
\hline
\end{tabular}

D.F.W., D.W. and Provent represent defeathered weight, dressed weight and proventriculus respectively. Organ and cut part weight expressed as percentage of dressed weight.

The increase in the size of the liver of quails fed Monodora myristica-free diet may have been as a result of the presence of antinutritional factors such as tannin, saponins, flavonoid and alkaloids. The liver has been reported to be the organ that tries to fight toxins present in diets. As a result of the detoxification activities, the liver enlarges. The enlarged liver weight of the birds fed the control diet could be an indication of stress. The low weight of liver observed in the groups fed Monodora myristica flavoured diets indicate that Monodora can effectively protect the liver from the free radicals that cause stress.

From the result, Monodora myristica was not detrimental to the quails with respect to the weight of organs and cut parts.

\section{References}

F.A.O. 1990. The Conservation and Sustainable utilization of plant Genetic Resources for food and
Agriculture. International technical Conference on plant Genetic Resources. Leipzig. Germany.

Daikwo, E. E., Tegulia, A., Kruise, J. R., Tamokou, J. D and Dongmo, M. 2011. Effects of ginger and garlic essential oils on growth performance and gut microbialpopulation of broiler chickens. Livestock Res. Rural dev. 21:131.

North, M. O. and Bell, D. D. 1990. Commercial chicken production manual. $4^{\text {th }}$ edition. Van Nostrand Reinhold, new York publishing company. P 45-49.

Salahudin, M. and Howlider, M. A. R. 1991. Effect of breed and season on egg quality traits of fowl. Indian $J$. Anim. Sci. 61:857-859.

Oluyemi, J. A. and Robert, F. A. 2000. Poultry production in the warm 
climate. Macmillan publishers Ltd. London. P34-39.

Fetuga, A., Majewaski, T. and Ceghowski J. 1976. Effect of Paprika in the diet on egg production in quails. $J$. Food and Technol 8:5.

Eke-Okoro, O. N. 1999. Genetic Erosion and its Implication in the conservation of root and tuber crops in Nigeria. Journal of Sustainable Agriculture and the Environment. Vol.1, No. 228-230.

A. O. A. C. 1990. Association of Official Analytical Chemists. Official Methods of Analysis $15^{\text {th }} \mathrm{edn}$. Washington D.C.

Duncan, D.B. 1952. Multiple range and multiple F-test Biometrics. 11: 142.

SPSS 2006. Statistical procedure for social sciences and facilities for release. McGraw-Hill Company, New York.

Wenk, C. 2002. Use of phytogenic products as feed additives for pigs and poultry. J. Anim. Sci. 86: 140-148.

Okoye, F.C., Ugwuene, M.C. and Mbara, J.U. 2006. Effect of local spices on the utilization of cassava peel mealbased diets by weaner rabbits. Pakistan Journal of nutrition 5 (3):203 -205

Ukoha, O. A. 2011. Evaluation of African Nutmeg (Monodora myristica) as feed additive in broiler diets. Ph.D. Dissertation. Michael Okpara University of Agric, Umudike. 85: 89.
Holdas, A. and May, K. N. 1966. Fish oil and fishy flavor of Eggs and carcasses of Hens Poultry Sci. 45: 1405-1408.

Samarasinghe, K. and Wenk, C. 2002. Tumeric (Curcuma longa) and manna oligosaccharides as antibiotic replaces in broiler diets. In. optimal Nutzung der futteres sourcen in xusammenspie, vonberg-und Talgebeit. Ein B e itragzumintertion len JahrderBery. Schriftenreiheausdm in stitunutzierwissenschaten. (Edn.M.kreuzer, Wenk. C. and lanziun, T.) 23: 124-125.

Ukachukwu, S. N. 2000. Chemical and nutritional evaluation of Mucunacochinchinensis (Lyon bean) as an alternative protein ingredient in broiler diets. Ph.D. thesis. UNN Nsukka 5-37.

Adeniji, A. A. and Balogun, O. O. 2000. Utilization of flavor treated bloodrumen content mixture in the diets of laying Hens. Nig. J. Anim. Prod. 29 (1) 34-39.

Jamroz, D. and Kamel, C. 2000. Plant extract enhance broiler performance. In: non ruminant Nutrition, antimicrobial and plant extracts on immunity, health and performance. J. Animal Science. 80 (1):41. 